\title{
ANALISIS STRUKTUR NARATIF TIGA BABAK FILM STORY OF KALE
}

\author{
Bernard Realino Danu Kristianto ${ }^{1}$, Adra Ophira Goenawan ${ }^{2}$ \\ ${ }^{1,2}$ Program Studi Ilmu Komunikasi, Universitas Bunda Mulia \\ (email: bkristianto@bundamulia.ac.id)
}

\begin{abstract}
Abstrak
Alur cerita yang dikemas dalam sebuah tontonan film tentunya menjadi modal utama keberhasilan film tersebut dalam menarik perhatian penonton. Dari berbagai genre yang ada, tidak banyak film drama Indonesia yang menggunakan alur mundur dalam penyajian ceritanya. Tujuan penelitian ini adalah untuk mengetahui tahapan dramatik tiga babak film Story of Kale dan alur yang digunakan dalam mengemas cerita film spin off garapan sutradara Angga Dwimas Sasongko. Metode penelitian yang digunakan adalah deskripsi kualitatif untuk melihat secara mendalam struktur naratif dan unsur dramatis yang digunakan mulai dari tahap awal, tahap tengah dan tahap akhir. Analisis data pada objek penelitian ini menggunakan teknik analisis struktur naratif tiga babak menurut Syd Field. Hasil analisis penelitian ini menemukan bahwa alur mundur yang disajikan dalam film Story of Kale tidak menggunakan kaidah struktur naratif tiga babak. Penggunaan struktur tiga babak terlihat dalam urutan kronologis cerita film Story of Kale tahap awal, munculnya persoalan dan konflik. Penelitian ini menyimpulkan bahwa penggunaan plot flashback dan teknik editing yang simultan dapat mengubah keseluruhan bentuk cerita naratif.
\end{abstract}

Kata kunci: alur, drama, Syd Field.

\begin{abstract}
This study discusses the narrative structure of the three-act film Story Of Kale by looking at the dramatic elements in the story presented. The purpose of this study was to determine the dramatic stages of the three-act film Story of Kale and the plots used in packaging the story of the spin-off film directed by Angga Dwimas Sasongko. The research method used is a qualitative description to see in depth the narrative structure and dramatic elements used starting from the early, middle and final stages. Analysis of the data on the object of this research uses the three-act narrative structure analysis technique according to Syd Field. The results of the analysis of this study found that the backward plot presented in the film Story of Kale does not use the rules of the three-act narrative structure. The use of a three-act structure is seen in the chronological order of the story of the early Story of Kale film, the emergence of problems and conflicts. This study concludes that the simultaneous use of flashback plots and editing techniques can change the overall form of the narrative story.
\end{abstract}

Keywords: storyline, drama, Syd Field.

\section{Introduction}

Di awal tahun 2020, media over the top menjadi alternatif tontonan yang paling digemari masyarakat. Selain karena terbatasnya jumlah bioskop sebagai imbas dari penutupan tempat publik yang dianggap rentan terjadinya penularan covid 19, aktivitas masyarakat yang lebih banyak dilakukan di rumah menjadikan layanan over the top mengalami peningkatan $80 \%$ di akhir tahun 2020 dibanding tahun-tahun sebelumnya. Fenomena peralihan media tayang ini menjadi salah satu hal yang menarik bila dikaitkan dengan bagaimana teknologi berkembang. Suatu teknologi tidak lain merupakan hasil 
konstruksi sosial dimana teknologi itu berada. Para ahli yang merancang suatu produk teknologi hanyalah agen teknis yang tunduk pada proses sosial antara produk teknologi dan masyarakat pengguna. Artinya teknologi bukanlah suatu identitas yang bebas nilai (Kristianto \& Marta, 2019a, p. 53). Sehingga menjadi hal yang wajar bila di era digital, media over the top menuai perhatian lebih bagi masyarakat penonton film. Salah satu sineas yang cukup memiliki upaya besar dalam merilis film di media digital dan menciptakan media bisnis over the top di tanah air adalah Angga Dwimas Sasongko. Keberhasilan film Nanti Kita Cerita Tentang Hari Ini yang dirilis di bioskop pada awal tahun 2020 sebelum masa pandemi, menjadikan media over the top yang ia buat sendiri - bernama Bioskop Online, menjadi salah satu alternatif media penayangan film yang mau tidak mau berkompetisi dengan media asing seperti Netflix, Disney+, HBO, dan media OTT lainnya.

Selain merilis film-film karya sutradara lain dan juga karyanya sendiri sebelumnya, secara perdana Angga Dwimas Sasongko juga merilis film yang ia sutradarai berjudul Story of Kale di platform Bioskop Online miliknya. Beberapa bulan kemudian, film tersebut juga dirilis kembali di media Netflix. Adapun Story of Kale menceritakan tentang seorang anak band bernama Kale yang menjalani hubungan dengan manajer bandnya sendiri bernama Dinda. Keinginan yang besar masing-masing tokoh baik Kale maupun Dinda dalam membahagiakan pasangannya justru menjadi hambatan dalam hubungan mereka. Meskipun sosok Kale hanya menjadi pemeran tambahan sebagai pasangan Awan dalam film NKCTHI akronim dari Nanti Kita Cerita Tentang Hari Ini, film Story of Kale menjadi spin off dari film NKCTHI, dimana menceritakan latar belakang karakter sosok Kale dan problematikanya dalam menjalin hubungan dengan Dinda. Masa lalu itulah yang akhirnya menjadikan Kale memiliki karakter yang tidak mudah untuk jatuh cinta yang sudah lebih dahulu muncul di film NKCTHI.

Istilah spin off sendiri memang sedang tren di kalangan bisnis film baik lokal maupun internasional. Dengan mengadopsi istilah perbankan (memisahkan aset perusahaan yang kemudian dijadikan perusahaan independen), di dalam film seringkali karakter tambahan justru menarik perhatian penonton, sehingga dibuatkan film sendiri berdasarkan karakter tersebut. Contoh film Hollwood yang menggunakan strategi spin off salah satunya adalah film Minions, yang merupakan spin off dari film Despicable Me yang sukses di pasaran. Karakter Minion mendapatkan perhatian lebih dari penonton, sehingga dibuatkan judul sendiri tanpa ada karakter lain yang muncul di Despicable Me. Contoh lain misalnya The Hobbit yang merupakan spin off dari film Lord Of The Ring, Han Solo yang merupakan spin off dari film Star Wars, karakter Wolverine yang dibuat film sendiri dari film The X Men. 
Karakter spin off yang dibuatkan judul sendiri dalam industri film adalah sebuah kewajaran, mengingat keuntungan pendapatan yang bisa didapatkan terlebih lagi bila si aktor memiliki nilai jual yang tinggi. Dengan berbekal karakter spin off melalui tokoh Kale yang diperankan oleh Ardito Pramono - yang juga sedang naik daun dengan karya-karya musik, ditambah dengan struktur cerita naratif percintaan, muncullah film Story of Kale sebagai spin off dari NKCTHI.

Dalam produksi sebuah film, struktur cerita menjadi salah satu kunci informasi dan pesan dapat diterima oleh penonton. Baik skala besar maupun kecil, struktur cerita Hollwood klasik masih sangat diminati oleh penonton. Di Indonesia, struktur cerita Hollwood klasik sering dikenal dengan struktur cerita tiga babak, yang mana dimulai dari babak pengenalan, babak pengembangan konflik, terakhir adalah babak resolusi. Struktur cerita tiga babak ini dianggap sebagai struktur cerita yang dapat membuat penulisan skenario menjadi lebih solid dan terperinci. Filosofi sederhananya terdapat pada kehidupan manusia itu sendiri, yang selalu dimulai dari permulaan, menemukan dan menghadapi persoalan hingga mengatasi persoalan tersebut dengan segala upaya dan hambatan yang dihadapi. Struktur cerita tiga babak yang sangat relevan dengan alur kehidupan manusia itu sendirilah yang menjadikan sebuah cerita dapat dinikmati dengan sangat mudah oleh penonton.

Banyak rumah produksi dengan alasan anggaran dan keuntungan yang sudah dikalkulasi, menjadikan Hollwood sebagai role model dan struktur tiga babak sebagai salah satu alat sekaligus senjata andalan kemasan filmnya. Dengan asumsi cerita dapat lebih mudah diterima oleh masyarakat, struktur tiga babak dipergunakan dalam mengemas cerita film, karena bagaimanapun kesuksesan sebuah film adalah diterimanya film tersebut oleh penonton atau masyarakat luas. Penggunaan struktur cerita tiga babak inipun seringkali dipergunakan oleh rumah produksi skala nasional di Indonesia.

Film-film Indonesia yang dapat dikategorikan box office tentunya menarik untuk dikaji dan ditelaah dalam konteks struktur cerita yang digunakan, bagaimana pengembangan alur ceritanya sehingga diterima oleh penonton, sehingga tiket terus menerus dibeli dan layar tetap bertahan selama beberapa waktu di bioskop tertentu. Namun, di era media over the top ini sangat relevan bila kajian juga mengarah ke platform yang relatif baru di Indonesia.

\section{Literature Review}

David Bordwell menjelaskan film sebagai perpaduan antara bentuk dan gaya (form and style), artinya film bukanlah kumpulan elemen acak yang menyatu, namun seperti halnya 
karya seni yang lain film memiliki bentuk. Melalui bentuk, dalam pengertian luas, adalah keseluruhan keterkaitan antara bagian-bagian dalam film (Bordwell et al., 2017, p. 52).

Unsur naratif dalam sebuah film memiliki bentuk struktur cerita yang dikemas sedemikian rupa sehingga menjadi keutuhan film. Struktur cerita naratif tentunya memiliki aturan yang sangat ketat, tidak seperti film non naratif yang lebih longgar dan fleksibel, pun sebagai perlawanan terhadap pakem cerita naratif.

\section{Gambar 1.}

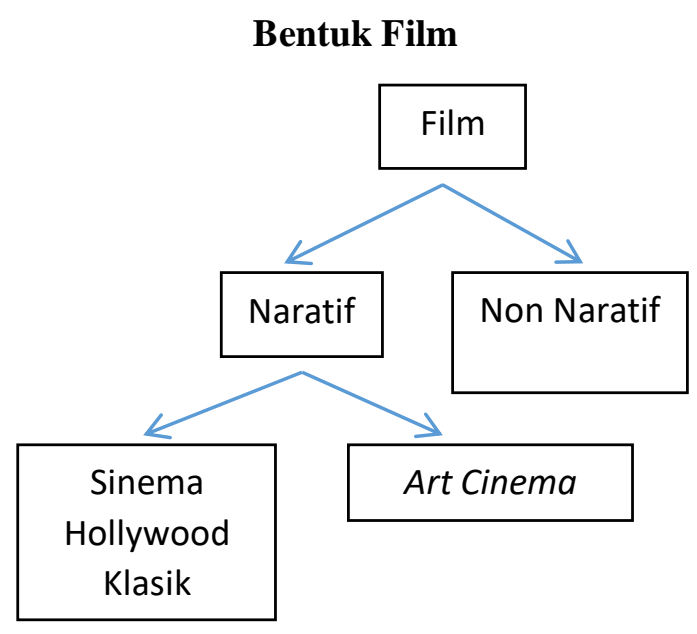

Sumber: Olahan Penulis

Di dalam bentuk sinema hollywood klasik, kepuasan penonton adalah hal utama kesuksesan film cerita dibuat. Penonton mengharapkan cerita yang memiliki hubungan sebab akibat yang logis, sehingga tidak muncul pertanyaan-pertanyaan atau bahkan membuat tidak mengerti. Biasanya plot diarahkan kepada motivasi satu atau dua karakter tokoh sentral yang menginginkan sesuatu. Keinginan karakter akan menetapkan tujuan yang ingin dicapai. Maka, pengembangan cerita akan berfokus pada proses dalam mencapai tujuan tersebut (Bordwell et al., 2017, p. 98). Dalam membuat film berbentuk klasik, pembuat film akan menyesuaikan logika waktu agar sesuai dengan sebab akibat progresi cerita. Film fiksi naratif seringkali terikat oleh keterkaitan antar plot yang disusun oleh logika sebab akibat (Ardiansyah et al., 2021, p. 8). Di luar cerita naratif, yang tidak memiliki hubungan kausalitas logika cerita, lebih cenderung sering digunakan pada bentuk art cinema.

Bentuk sinema hollwood klasik memiliki sistem struktur yang mengatur peristiwa, ruang dan waktu dalam cerita sehingga memiliki hubungan sebab akibat yang logis. Struktur tersebut dikenal dengan struktur tiga babak, yaitu babak 1 - permulaan (opening), babak 2 tengah (middle), dan babak 3 - akhir (ending). Tahap permulaan merupakan tahap yang 
paling krusial dalam sebuah cerita film, karena merupakan awal sebuah peristiwa terjadi. Tahap pertengahan merupakan tahap yang paling lama dan biasanya paling panjang dalam durasi sebuah film cerita. Di tahap ini pula protagonis atau tokoh utama melakukan sejumlah usaha untuk mencari solusi dan beraksi untuk mencapai tujuan atas masalah yang timbul di tahap permulaan. Tahap akhir adalah penutup dari klimaks sebuah cerita, klimaks itu sendiri merupakan puncak konflik tokoh dengan hambatannya dalam mencapai tujuannya. Di tahap ini tempo dari cerita mulai menurun hingga berakhirnya film (Firziandini et al., 2018, p. 141).

Syd Field dalam bukunya yang berjudul Screenplay memaparkan bahwa struktur tiga babak bisa dibagi melalui skenario cerita yang ada. Satu halaman skenario mewakili kira-kira satu menit durasi film. Jadi jika film berdurasi 90 menit sampai 120 menit, maka jumlah halaman skenario berkisar 90 hingga 120 halaman. Dari pembagian tersebut, untuk film berdurasi dua jam atau 120 menit, maka babak satu dimulai dari halaman 1 hingga 30, babak dua dimulai dari halaman 31 hingga 90, babak tiga dimulai dari halaman 92 hingga 120 (Bianus, 2017, p. 217).

\section{Gambar 2.}

\section{Struktur Tiga Babak Syd Field}

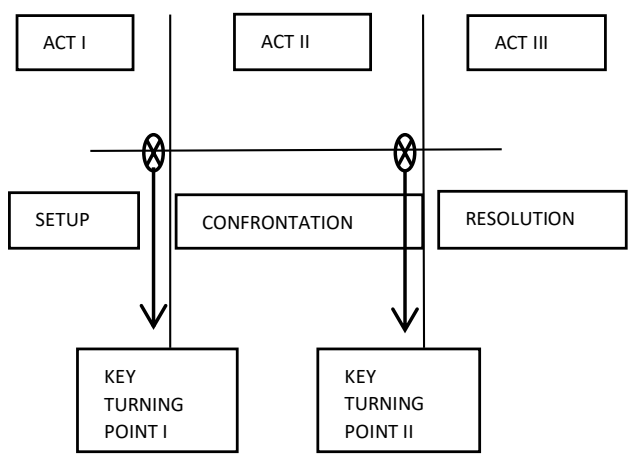

Sumber: (Field, 2005, p. 90)

\section{Methods}

Penelitian ini menggunakan metode penelitian kualitatif yang bersifat deskriptif. Metode kualitatif dipilih karena penelitian dilakukan menggunakan pendekatan struktur naratif dan unsur dramatik. Pendekatan struktur naratif tiga babak digunakan untuk melihat tahapan dan pembagian sistematis cerita yang disampaikan. Pendekatan unsur dramatik yang digunakan mengacu pada pemetaan dramatik dari struktur yang dibuat oleh Syd Field dalam bukunya Screenplay. Struktur yang sejatinya sudah diperkenalkan oleh Aristoteles dan secara 
turun temurun terbukti efektif dalam menyampaikan berbagai macam bentuk cerita ini memiliki penekanan dramatik di setiap babaknya.

Pada babak perkenalan, protagonis atau tokoh utama diperkenalkan dalam kegiatan sehari-hari untuk menunjukkan karakternya. Pengenalan ini penting untuk menunjukkan kepada penonton siapa tokoh yang ada di dalam cerita dan akan seperti apa perkembangan cerita sebelum menemui persoalan atau permasalahan. Tentunya menjadi sangat penting babak perkenalan harus menimbulkan ketertarikan bagi penonton. Terdapat beberapa unsur dramatik dalam bagian perkenalan; inciting incident, plot point atau key turning point 1.

Babak tengah dimulai dari kondisi ketika tokoh utama memutuskan untuk mewujudkan apa yang menjadi tujuannya. Babak ini merupakan babak yang memiliki porsi lebih banyak dibanding babak yang lain. Dalam babak tengah, kompleksitas cerita terus bergulir dan berkembang, semakin karakter utama tenggelam dalam persoalan, semakin menarik perhatian penonton untuk terus mengikuti jalan hidupnya. Pada babak ini juga terdapat plot point atau key turning point 2. Key turning point 2 sering disebut juga the lowest point karena pada titik ini karakter cerita berada dalam titik terendah. Dalam film aksi biasanya, di titik inilah tokoh utama sering kali mengalami kekalahan dan memunculkan motivasi besar untuk memenangkan konflik. Biasanya untuk dramatisasi cerita, jika bagian akhir tujuan tokoh utama tercapai, pada key turning point 2, tokoh utama digambarkan mengalami kegagalan total dalam mencapai tujuannya. Begitu sebaliknya jika bagian akhir tokoh utama mengalami kegagalan dalam mencapai tujuan, maka key turning point 2 digambarkan seolah berhasil mencapai tujuan.

Babak akhir merupakan bagian munculnya resolusi atas persoalan. Resolusi yang dilakukan bisa mencapai tujuan utama, atau sebaliknya justru tidak tercapai. Dalam babak ini, semua masalah yang sudah diperkenalkan dan berkembang pada babak awal dan tengah sudah harus terselesaikan. Prinsipnya adalah terjawabnya tujuan yang sejak awal diwujudkan karakter, pada akhirnya apakah berhasil atau gagal. Dalam cerita aksi, di bagian ini biasanya tokoh utama berjuang dalam pertarungan sehingga pilihannya adalah berhasil mengalahkan lawan atau gagal bahkan mati. Di babak akhir ini selain resolution juga terdapat climax dimana puncak konflik dan atau pertarungan karakter utama terhadap hambatan yang dihadapi.

Adapun yang menjadi obyek material penelitian ini adalah film Story of Kale yang disutradarai oleh Angga Dwimas Sasongko dan sudah ditayangkan pada platform OTT seperti Netflix. Sedangkan obyek formal dalam penelitian ini adalah dramatisasi cerita film Story of 
Kale yang akan dianalisis menggunakan struktur tiga babak dan diperkuat oleh alur cerita yang digunakan sebagai kemasan film.

\section{Results}

Dari hasil observasi dan pengumpulan data melalui tayangan film Story of Kale, didapatkan rangkaian adegan yang dikemas dari menit awal hingga akhir bahwa setting masa sekarang dipadukan dengan setting masa lalu. Setting masa sekarang difokuskan pada adegan Kale dan Dinda di rumah, sedangkan setting masa lalu bervariasi mulai dari adegan di backstage, studio, dalam bus perjalanan, dan kamar hotel.

Tabel 1.

Urutan scene film Story of Kale

\begin{tabular}{|c|c|c|c|}
\hline No & Scene & Deskripsi & Log Time \\
\hline 1 & Opening title & Bioskop Online, Visinema Content & $00.00 .00-00.00 .49$ \\
\hline 2 & Scene rumah & Dinda meminta putus dari Kale & $00.00 .50-00.01 .41$ \\
\hline 3 & Title & Story Of Kale, When Someone's Love & $00.01 .42-00.01 .55$ \\
\hline 4 & $\begin{array}{l}\text { Scene } \\
\text { backstage } \\
\text { (flashback) }\end{array}$ & $\begin{array}{l}\text { Dinda dan Argo terlibat dalam } \\
\text { pertengkaran ketika band Arah dan Kale } \\
\text { sedang mempersiapkan penampilan. Kale } \\
\text { dan Argo terlibat dalam perkelahian } \\
\text { karena Argo terlihat mendorong badan } \\
\text { Dinda. }\end{array}$ & $00.01 .56-00.13 .30$ \\
\hline 5 & Scene rumah & $\begin{array}{l}\text { Dinda memasukkan baju-baju ke dalam } \\
\text { koper sementara Kale mempertanyakan } \\
\text { sebab Dinda menginginkan putus, Dinda } \\
\text { mengatakan bahwa ia sudah berselingkuh }\end{array}$ & $00.13 .31-00.19 .01$ \\
\hline 6 & $\begin{array}{l}\text { Scene studio } \\
\text { (flashback) }\end{array}$ & $\begin{array}{l}\text { Kale membawa Dinda ke studio band. } \\
\text { Ketika Dinda berniat untuk bertemu } \\
\text { dengan Nina, adik Argo, Kale } \\
\text { memberikan pilihan kepada Dinda untuk } \\
\text { tetap di studio mengerjakan proyek lagu } \\
\text { bersama Kale atau pergi menemui Nina. } \\
\text { Dinda memilih untuk tetap di studio }\end{array}$ & $00.19 .02-00.29 .41$ \\
\hline 7 & Scene rumah & $\begin{array}{l}\text { Kale menahan kepergian Dinda dengan } \\
\text { mengambil kunci pintu rumah, Dinda } \\
\text { berusaha merebut kunci tersebut. Kale } \\
\text { mempertanyakan mengapa Dinda tega } \\
\text { berselingkuh. Sedangkan Dinda merasa } \\
\text { bahwa sudah lama tidak menjadi diri } \\
\text { sendiri. }\end{array}$ & $00.29 .42-00.39 .01$ \\
\hline 8 & $\begin{array}{l}\text { Scene bus } \\
\text { (flashback) }\end{array}$ & $\begin{array}{l}\text { Kale, band Arah dan Dinda berada di } \\
\text { dalam bus yang sedang melaju. Kale } \\
\text { memperhatikan Dinda yang tampak } \\
\text { memberikan perhatian kepada anggota } \\
\text { band Arah. Di pemberhentian, Kale } \\
\text { menyatakan perasaan cinta dan ingin } \\
\text { membangun hubungan spesial dengan }\end{array}$ & $00.39 .02-00.47 .21$ \\
\hline
\end{tabular}


$9 \quad$ Scene rumah

$10 \quad$ Scene studio (flashback)

11 Scene rumah

12 Scene rumah (flashback)

13 Scene rumah

14 Scene hotel (flashback)

15 Scene rumah

16 Credit title

17 Post Credit Scene studio
Dinda, Dindapun menerimanya

Kale ingin memperbaiki hubungan dari awal lagi, namun Dinda sudah tidak mau melanjutkan hubungan mereka. Kale rela melakukan apa saja demi kebahagiaan dan keberadaan Dinda tetap di rumah. Dinda meminta Kale melepas dirinya dan untuk tidak membuat pengecualian seperti halnya Kale meminta Dinda melepas Argo karena sudah menyakitinya.

Band Arah, Kale dan Dinda sedang mengerjakan proyek lagu. Kale merasa tidak senang karena Dinda memberikan lagu ciptaannya untuk band Arah dan bukan eksklusif untuk Kale dan Dinda. Namun karena Dinda merasa band Arah sudah seperti keluarga sendiri, Kale mengalah.

Kale bersikeras bahwa dirinya berjanji untuk bisa memastikan kebahagiaan Dinda, namun Dinda membantah bahwa tidak ada yang bisa bertanggungjawab terhadap kebahagiaan orang lain selain dirinya sendiri. Kale merasa sedih, dan memainkan instrumen lagu ciptaan mereka.

Kale memainkan sebuah lagu, dan Dinda menemani di sampingnya. Mereka menikmati waktu berdua di rumah

Dinda mengaku bahwa ia tidak hanya berselingkuh namun juga akan menikah. Kale merasa hal tersebut tidak adil baginya. Dinda memeluk erat Kale.

Kale melihat Argo dan segera menuju kamar Dinda, ia mempertanyakan dan mencurigai Dinda atas kehadiran Argo di kamar hotel. Dinda berdalih bahwa Argo hanya ingin berpamitan, namun Kale tidak terima dan membanting beberapa barang di kamar hotel.

Kale membukakan pintu dan membiarkan Dinda pergi. Dalam kesedihan, Kale memainkan sebuah lagu.

Rolling title

$00.55 .32-00.59 .12$

$00.59 .13-01.00 .41$

$01.00 .42-01.03 .22$

$01.03 .23-01.09 .41$

Kale dan band Arah memainkan lagu.

$01.12 .40-01.14 .41$

$01.14 .42-01.17 .55$

Kale mengaku ingin berhenti menjadi pemain band dan ingin fokus menjadi produser sekaligus manager band Arah

$01.09 .42-01.12 .39$

Sumber: Olahan Penulis 
Badruzamman (2020) dalam (Cahaya Tarsisty et al., 2021, p. 139) bahwa setiap cerita naratif memiliki dua bagian penting: yang pertama tentunya adalah sebuah cerita, isi atau rangkaian peristiwa (tindakan, kejadian), yang kedua adalah eksisten (karakter). Dalam sebuah cerita, latar belakang, personal history, pekerjaan, kedekatan dengan orang tua, serta masa kecil tokoh (Field, 2005, p. 77), seharusnya muncul sedikit demi sedikit untuk memberikan gambaran karakter tokoh itu sendiri termasuk dalam mengambil keputusan dan prinsip dalam hidupnya. Kale tergambarkan sebagai seorang musisi dan pencipta lagu yang selalu ingin memperjuangkan kebahagiaan orang lain karena trauma masa lalu orang tuanya. Ayahnya meninggalkan ibunya dan kemudian sang ibu turut meninggalkan dirinya membuat Kale merasa ia harus selalu ada untuk orang lain agar orang tersebut bahagia. Itulah yang ia upayakan untuk Dinda. Berbeda halnya dengan Dinda, seorang manager band yang juga pencipta lagu, bercermin dari sosok ibunya yang senantiasa bersabar dalam menghadapi ayahnya yang kasar. Sang ibu rela bertahan dalam hubungan rumah tangga seperti itu dengan harapan suatu saat ketika ayahnya berubah, ia masih ada dan setia di sampingnya. Harapan dan ambisi seperti itulah yang menjadikan Dinda merasa kuat dalam menghadapi Argo yang temperamen dan kasar. Namun setelah Dinda mengenal Kale, ia merasa hal tersebut tidaklah benar dan ia harus menjadi diri sendiri.

Selain karakter, rangkaian peristiwa atau plot menjadi unsur penting dalam sebuah cerita. Menurut Holman dalam (Aristo, 2018, p. 4), pada dasarnya plot memiliki 2 jenis, plot kronologis dan plot kilas balik atau flashback. "Chronological order is all events that occur in the order in which they happened in writing”, artinya urutan kronologis merupakan semua kejadian yang tertulis pada tahap penulisan. Holman melanjutkan bahwa bisa jadi terdapat urutan peristiwa masa lalu hingga masa depan yang ditulis dalam urutan waktu yang jelas. Sedangkan flashback dijelaskan Holman, "flashback is interjected scene that takes the narrative back in the time from the current point the story has reached". Bila melihat konteks film Story of Kale, melalui visual adegan flashback, penonton diajak untuk membawa naratif ke masa lalu ketika Kale dan Dinda berkenalan hingga mencapai titik masa sekarang ketika Dinda meminta putus dari Kale.

\section{Urutan Kronologis Cerita Dalam Struktur Tiga Babak Story Of Kale}

\section{Tahap Awal}

Berdasarkan pengamatan terhadap film Story of Kale dan unsur dramatik setiap babak yang secara implisit terdapat di dalam plot cerita, alur cerita maju digunakan sebagai basic 
story naratif film tersebut. Babak pengenalan atau tahap awal dimulai dari ketika tokoh Argo dan Dinda berselisih paham di belakang panggung sebuah pertunjukkan musik.

\section{Gambar 3.}

\section{Kale melakukan soundcheck}

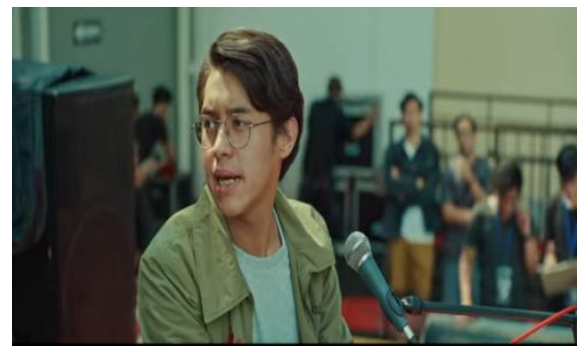

Sumber: Cuplikan Film Story of Kale di Netflix

\section{Gambar 4.}

Dinda berselisih paham dengan Argo

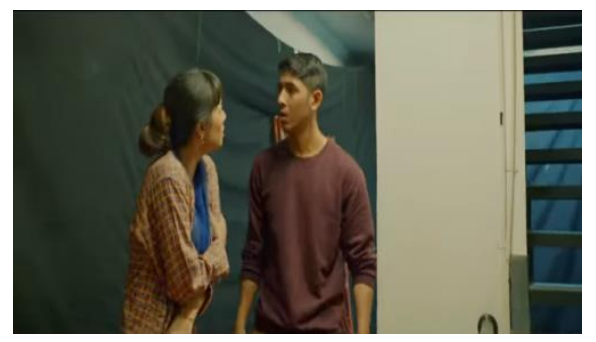

Sumber: Cuplikan Film Story of Kale di Netflix

Adegan Kale melakukan soundcheck dan beberapa anggota band yang menyapa dapat dikategorikan sebagai kondisi status quo tokoh Kale yang tanpa ketergangguan. Argo dan Dinda yang berselisih paham karena Dinda yang ingkar janji terhadap Argo juga bisa dianggap sesuatu yang wajar dalam hubungan asmara sepasang kekasih. Namun masalah yang masih dianggap wajar dan terkesan "tidak ada apa-apa" ini tidak boleh berlangsung lama (Cendekia, 2020, p. 39). Status quo harus berakhir oleh sebuah peristiwa yang merusak tatanan karakter utama yang seimbang dan tanpa gangguan. Inciting incident sebagai rangsangan pemunculan masalah (Erwani, 2017, p. 44) dalam film Story of Kale terdapat pada adegan ketika Argo melanjutkan protes terhadap sikap Dinda di luar ruangan, dan mereka berselisih paham hingga mengundang rasa penasaran Kale untuk datang mendekat. The key incident and Plot Point I happen to be the same thing. There are times when this happens, and other times when it doesn't. The inciting incident and the key incident are related, but not always in the same way. It all depends on the story you're telling (Field, 
2005, p. 136). Syd Field menjelaskan dalam buku Screenplay bahwa seringkali key turning point dan inciting incident bisa jadi merupakan kejadian yang sama, bisa jadi berbeda, namun selalu berhubungan. Bila menilik dari adegan cerita film Story of Kale dapat dilihat bahwa momen ketika Argo mendorong Dinda kemudian Kale memutuskan untuk memukul Argo karena perbuatannya terhadap Dinda menjadi Key turning point 1 atas munculnya persoalan Argo memperlakukan Dinda secara kasar dengan mendorongnya hingga terjatuh.

\section{Gambar 5.}

Kale hendak memukul Argo

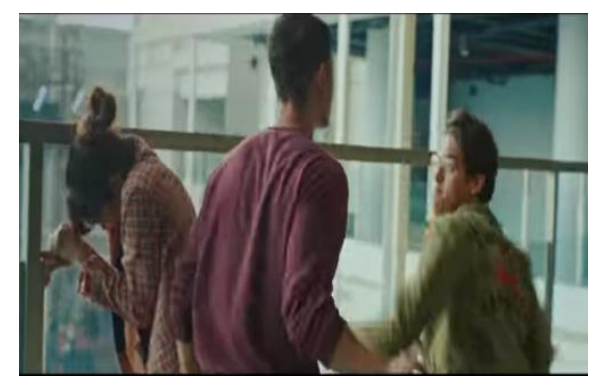

Sumber: Cuplikan Film Story of Kale di Netflix

\section{Tahap Tengah}

Babak tengah dalam film ini dimulai dari adegan setelah perkelahian Argo dan Kale disambung ke dialog konflik kecil antara Kale dan Dinda, serta kerisauan dan tuntutan perhatian yang dirasakan Kale kepada Dinda.

\section{Gambar 6.}

Kale dan Dinda berselisih paham tentang project lagu ciptaan Dinda

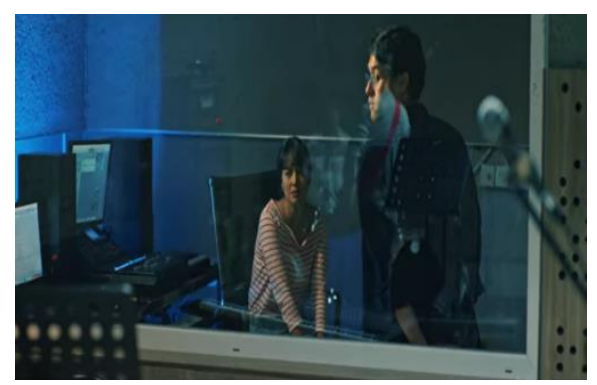

Sumber: Cuplikan Film Story of Kale di Netflix 


\section{Gambar 7.}

Kale meminta maaf kepada Dinda

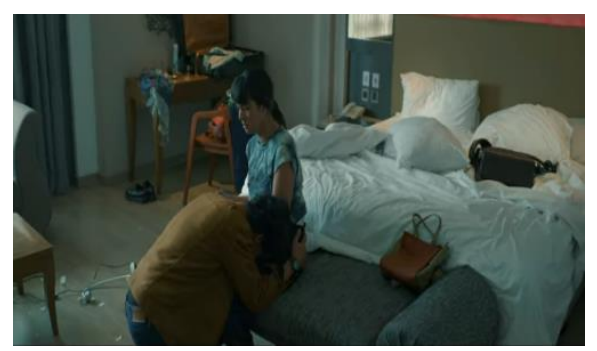

Sumber: Cuplikan Film Story of Kale di Netflix

Di dalam adegan rumah, ketika Kale sedang bermain piano tiba-tiba Dinda meminta putus. Peristiwa ini menjadi titik key turning point 2 yang menandakan awal memuncaknya perseteruan konflik tokoh Kale dan Dinda yang sama-sama memiliki persoalan dalam dirinya dalam menghadapi pasangannya.

\section{Gambar 8.}

Kale bertanya alasan Dinda meminta putus

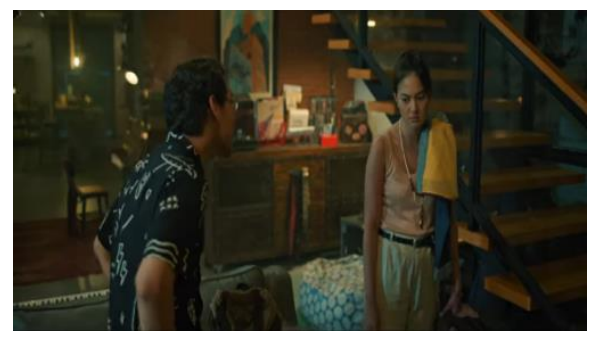

Sumber: Cuplikan Film Story of Kale di Netflix

\section{Gambar 9.}

Kale dan Dinda berdebat mengenai hubungan mereka

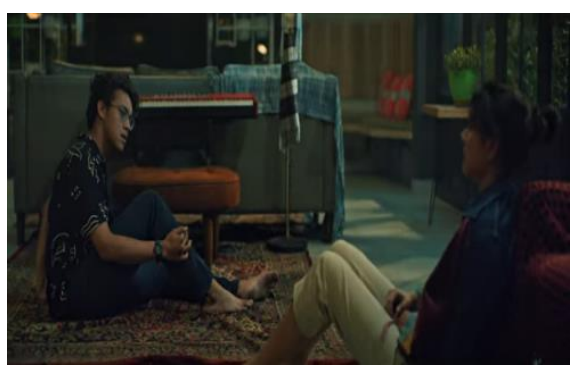

Sumber: Cuplikan Film Story of Kale di Netflix 


\section{Tahap Akhir}

Babak akhir cerita film Story of Kale ditandai ketika adegan Kale bertanya kepada Dinda sejak kapan ia merasa pikirannya sudah "tidak ada" di rumah. Inilah momen dimana perseteruan konflik antara Kale dan Dinda mencapai klimaks dalam perjalanan cerita film Story of Kale. Setelah itu Dinda mendekati dan memeluk Kale. Kale yang merasa bahwa semuanya tidak adil bagi dirinya, berusaha memahami semua yang terjadi dalam dirinya. Antiklimaks konflik Kale dan Dinda ditutup dengan pengakuan Dinda atas ketidakadilan tersebut dan ia berterimakasih kepada Kale karena sudah membawa mereka sampai di titik itu dengan cinta yang diyakini Kale. Kale membukakan pintu rumah dan membiarkan Dinda meninggalkannya. Pada momen ini akhir cerita ditampilkan sebagai kondisi yang tidak bahagia. Hal ini sejalan dengan apa yang dikatakan Misbach Yusa Biran dalam penelitian Budiman Akbar bahwa Misbach menjelaskan bahwa dalam babak akhir ini menyediakan kesempatan bagi penonton memahami dan menarik kesimpulan akhir cerita yang happy ending ataupun unhappy ending. Penonton diajak dan diberi kesempatan untuk meresapi kegembiraan yang ditimbulkan oleh happy ending atau rasa sedih yang ditimbulkan oleh unhappy ending (Akbar, 2017, p. 120). Rasa sedih yang teramat dalam diekspresikan Kale melalui permainan piano di akhir film. Setelah credit title berakhir, ditampilkan post credit scene yang menampilkan band Arah dan Kale sedang memainkan sebuah lagu. Setelah lagu tersebut dimainkan, Kale menceritakan bahwa ia akan berhenti menjadi seorang pemain band dan ingin memproduseri band Arah sekaligus menjadi manager band tersebut. Post credit scene ini sekaligus menjadi penyambung cerita film Nanti Kita Cerita Tentang Hari Ini dimana Kale diperkenalkan sebagai seorang produser band yang eksentrik (Asri, 2020, p. 82) dan memiliki prinsip bahwa ia tidak mau bertanggungjawab atas kebahagiaan orang lain ${ }^{1}$.

Tabel 2.

Urutan Kronologis Dalam Struktur Tiga Babak

\begin{tabular}{|c|c|c|c|c|}
\hline No & Scene & Plot & Deskripsi & Tahapan \\
\hline \multirow[t]{4}{*}{1} & Scene & $\mathrm{a}$ & Kale melakukan soundcheck & Awal / Opening/ \\
\hline & backstage & & $\begin{array}{l}\text { Dinda dan Argo terlibat dalam } \\
\text { pertengkaran }\end{array}$ & \\
\hline & & $b$ & $\begin{array}{l}\text { Kale dan Argo terlibat dalam } \\
\text { perkelahian karena Argo terlihat } \\
\text { mendorong badan Dinda }\end{array}$ & $\begin{array}{l}\text { Key turning } \\
\text { point } 1\end{array}$ \\
\hline & & $\mathrm{c}$ & $\begin{array}{l}\text { Kale menyampaikan kepada Dinda } \\
\text { bahwa ia layak mendapatkan yang } \\
\text { lebih baik }\end{array}$ & Tengah / Middle \\
\hline 2 & $\begin{array}{l}\text { Scene } \\
\text { studio }\end{array}$ & - & $\begin{array}{l}\text { Kale membawa Dinda ke studio } \\
\text { band.Namun ketika Dinda berniat }\end{array}$ & \\
\hline
\end{tabular}

\footnotetext{
${ }^{1}$ Dialog Kale dalam film Nanti Kita Cerita Tentang Hari Ini.
} 
3 Scene bus a

4

Scene
studio

5 Scene -

hotel

6

$\begin{array}{ll}\text { Scene } & \mathrm{a} \\ \text { rumah } & \end{array}$

b

d

c Kale menahan kepergian Dinda

untuk bertemu dengan Nina, adik Argo, Kale memberikan pilihan kepada Dinda untuk tetap di studio mengerjakan proyek lagu bersama Kale atau pergi menemui Nina. Dinda memilih untuk tetap di studio

Kale, band Arah dan Dinda berada di dalam bus yang sedang melaju. Kale memperhatikan Dinda yang tampak memberikan perhatian kepada anggota band Arah.

b Di pemberhentian, Kale menyatakan perasaan cinta dan ingin membangun hubungan spesial dengan Dinda, Dindapun menerimanya

Band Arah, Kale dan Dinda sedang mengerjakan proyek lagu. Kale merasa tidak senang karena Dinda memberikan lagu ciptaannya untuk band Arah dan bukan eksklusif untuk Kale dan Dinda. Namun karena Dinda merasa band Arah sudah seperti keluarga sendiri, Kale mengalah.

Kale melihat Argo dan segera menuju kamar Dinda, ia mempertanyakan dan mencurigai Dinda atas kehadiran Argo di kamar hotel. Dinda berdalih bahwa Argo hanya ingin berpamitan, namun Kale tidak terima dan membanting beberapa barang di kamar hotel.
Dinda meminta putus dari Kale
Key turning
point 2

Dinda memasukkan baju-baju ke dalam koper sementara Kale mempertanyakan sebab Dinda menginginkan putus, Dinda mengatakan bahwa ia sudah berselingkuh dengan mengambil kunci pintu rumah, Dinda berusaha merebut kunci tersebut. Kale mempertanyakan mengapa Dinda tega berselingkuh. Sedangkan Dinda merasa bahwa sudah lama tidak menjadi diri sendiri.

Kale ingin memperbaiki hubungan dari awal lagi, namun Dinda sudah tidak mau melanjutkan hubungan mereka. Kale rela melakukan apa 


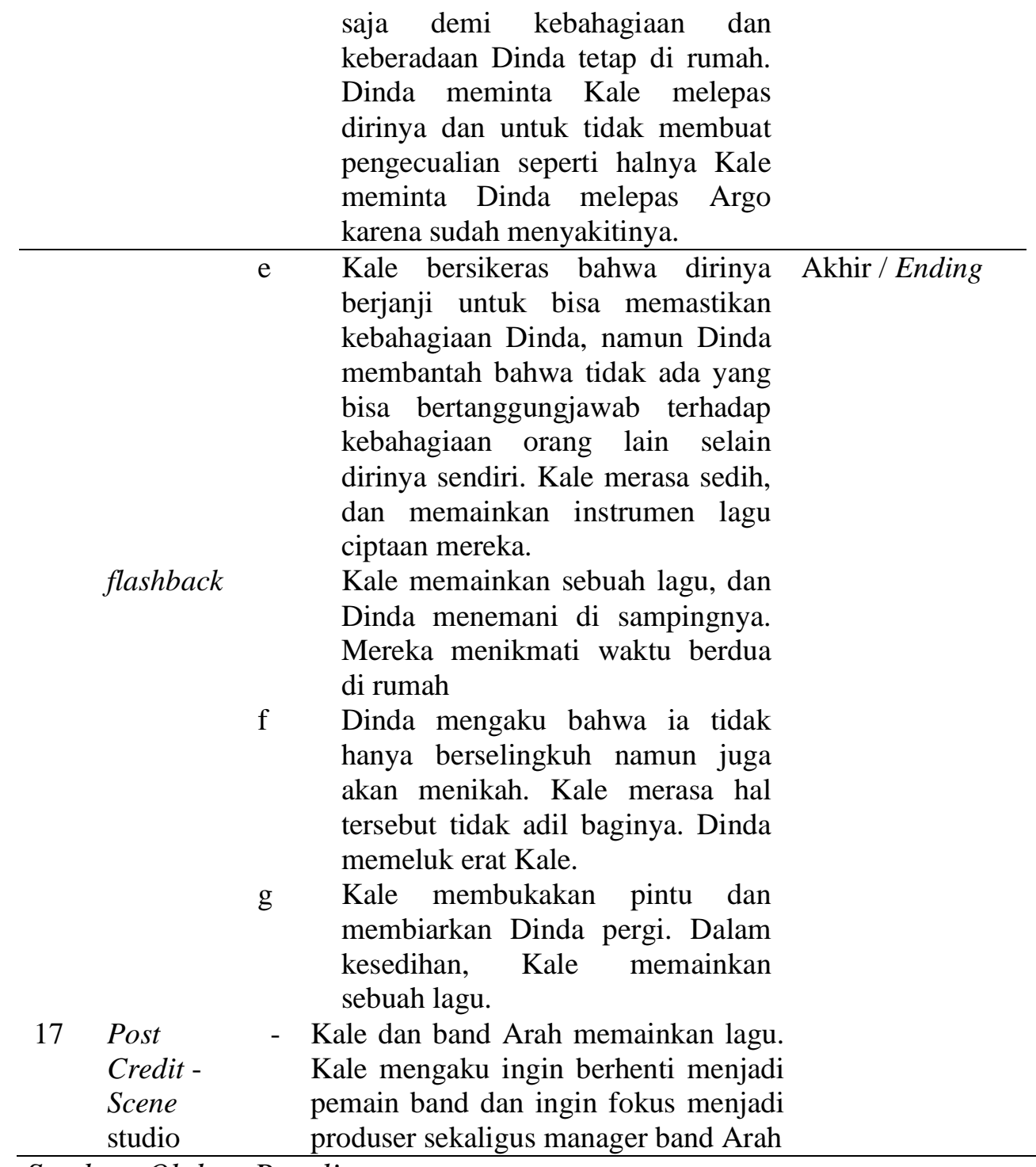

Sumber: Olahan Penulis

\section{Discussion}

Perseteruan Kale dan Dinda sebenarnya dipicu oleh pandangan masing-masing individu dalam melihat dan mengupayakan kebahagiaan. Kale merasa bahwa ia bertanggungjawab dalam membahagiakan Dinda hingga sudah berada di tahap dimana segala sesuatu ia perjuangkan, namun ia juga menuntut Dinda untuk tidak bersikap diam. Berbeda halnya dengan Dinda, ia justru memiliki prinsip bahwa kebahagiaan hanya bisa setiap orang bertanggungjawab atas kebahagiaannya sendiri dan bukan kebahagiaan orang lain. Hal ini sejalan dengan apa yang dipaparkan oleh Martin dan Thomas dalam (Kristianto \& Marta, 2019b, p. 100). Melihat unsur intrinsik sebuah cerita film sama halnya cerita karya sastra. Unsur intrinsik yang merupakan unsur pembangun pada sebuah karya sastra yang berasal dari dalam karya itu sendiri. Pada sebuah film unsur intrinsik berupa, tema, plot/alur, penokohan, 
latar, sudut pandang, gaya bahasa, dan amanat (Sari et al., 2020, p. 23). Dalam pembahasan ini yang menjadi fokusnya adalah penggunaan plot atau alur cerita dalam sajian film Story of Kale. Penyampaian alur dibagi menjadi tiga yaitu, alur maju, mundur, dan campuran. Alur maju merupakan alur yang menggambarkan kejadian atau peristiwa yang berkesinambungan dari awal hingga akhir cerita. Alur mundur merupakan alur yang menggambarkan rangkaian peristiwa dalam cerita menggunakan teknik flashback atau menampilkan gambaran cerita dari akhir ke awal. Sementara alur campuran merupakan alur yang menggambarkan cerita secara acak bagian awal, tengah dan akhir (Amalia et al., 2019, p. 224). Berbeda dengan format kemasan film kebanyakan, film Story of Kale ditampilkan dalam kemasan yang berbeda dari struktur naratif utama cerita. Struktur naratif cerita asli dikemas dengan menggunakan alur mundur dalam menceritakan masa lalu perjalanan hubungan Kale dan Dinda. Pemotongan adegan masa sekarang yang dikombinasikan dengan adegan flashback menjadikan cerita film disampaikan melalui alur mundur.

Film bukanlah sekedar gambar pada layar namun juga penyajian (Nurhablisyah \& Susanti, 2020, p. 320). Sebagai sebuah sajian, dalam kemasan filmnya, penonton disajikan dua bagian segmen, yang pertama adalah segmen utama film yaitu adegan Dinda ingin mengakhiri hubungan dengan Kale yang menggunakan setting rumah di masa sekarang (present). Keseluruhan scene rumah bercerita tentang perdebatan antara Kale dan Dinda. Di dalam adegan utama tersebut Kale dan Dinda saling mempertanyakan dan mempertahankan argumennya dalam hal idealisme pribadi masing-masing. Kale memiliki idealisme bahwa ia mengupayakan segala hal demi membahagiakan Dinda, yang secara tidak disadari menimbulkan rasa dan sikap posesif yang dianggap Dinda terlalu berlebihan. Banyak hal yang dibuat Kale justru dirasa Dinda mengekang dirinya. Bagi Dinda hubungan yang cenderung mengarah kepada toxic tersebut menimbulkan perasaan ingin berpisah yang sudah tidak bisa dibendung lagi. Segmen kedua yang ditampilkan dalam film Story of Kale merupakan adegan-adegan berkaitan dengan hubungan Kale dan Dinda di waktu sebelumnya (past) sejak Dinda memutuskan hubungan dari Argo. Adegan tersebut diantaranya; adegan Kale memisahkan perselisihan antara Argo dan Dinda, Kale dan Dinda bercengkerama di dalam studio, Kale dan Dinda berada dalam bus di sebuah perjalanan bersama anggota band Arah, Kale dan Dinda berselisih paham karena Dinda memilih band Arah yang memainkan lagu yang Kale dan Dinda ciptakan, Kale dan Dinda terlibat perselisihan di hotel setelah Dinda bertemu dengan Argo. Adegan-adegan diletakkan sebagai sisipan adegan flashback yang ditampilkan secara simultan sebagai informasi dalam menambah dramatisasi konflik perdebatan Kale dan Dinda di rumah. 
Berdasarkan kemasan akhir yang ditampilkan kepada penonton, bila kemudian ditelaah menggunakan struktur naratif tiga babak, dapat dilihat bahwa awal film dibuka oleh konflik dan persoalan. Dinda yang meminta putus dari Kale disambung oleh flashback awal mula kedekatan Kale dan Dinda. Setelah adegan Kale melerai perselisihan Argo dan Dinda, cerita disambung ke situasi di rumah ketika Kale mempertanyakan mengapa Dinda menginginkan untuk mengakhiri hubungan mereka. Perselisihan mereka di rumah karena Dinda menceritakan bahwa dirinya sudah berselingkuh disambung dengan adegan ketika Kale dan Dinda bercengkerama di studio dan untuk pertama kalinya Kale dan Dinda berciuman. Perseteruan dan perdebatan di rumah tersebut selalu disisipkan adegan flashback hubungan Kale dan Dinda di luar rumah. Yang menjadi poin penting dalam kemasan alur mundur (insert flashback) cerita film Story of Kale ini adalah struktur naratif tiga babak yang menjadi urutan kronologis cerita Story of Kale dengan alur maju yang kemudian diberi adegan sela atau sisipan melalui proses editing. Struktur naratif menggunakan plot adegan flashback dari menit awal film hingga akhir menit ke 77 tersebut tentunya tidak dapat dilihat dalam kaidah struktur naratif tiga babak karena unsur dramatiknya tidak berada pada posisi yang sesuai dengan kaidah tersebut. Hal demikian memang menjadi konsep alur yang tampaknya juga dilakukan secara konsisten di film sebelumnya - Nanti Kita Cerita Tentang Hari Ini. Tujuan memberikan gaya yang serupa dengan penggunaan alur mundur pada kemasan editing filmnya, sejalan dengan konsep yang dipaparkan Christian Metz bahwa film "berbicara" kepada audiens dengan menggerakkan gambar satu dengan yang lain dimana berarti berkomunikasi. Melalui proses editing, memilih shot dan menyatukan gambar, teks dan musik ke dalam sebuah adegan (Kholisoh et al., 2021, p. 46). Di titik ini terlihat jelas Angga Dwimas Sasongko sebagai sutradara memberikan pesan bahwa film Story of Kale memiliki keterkaitan yang erat dari jalinan cerita dan struktur dramatiknya dengan film sebelumnya.

Di dalam menggunakan alur mundur tersebut, teknik editing crosscutting juga digunakan untuk menghubungkan shot satu dengan yang lain. Shot yang berbeda ruang dan waktu tersebut dipadukan secara tematik pada dialog Kale dan Dinda. Hal ini sejalan dengan apa yang dipaparkan Prajanata Mulia dalam penelitiannya pada film Haji Backpacker bahwa teknik crosscutting menyatukan ketidaksinambungan antar dua adegan untuk menciptakan pengembangan konflik (Mulia, 2017, p. 200). Seperti halnya di bagian awal film, terdapat adegan Kale dan Dinda bercengkerama di balkon dimana Kale mengatakan bahwa Dinda layak mendapatkan yang lebih baik dari Argo, yaitu Kale yang sudah rela dipukuli hingga memar dan kacamatanya pecah, sesaat mereka tertawa bersama. Adegan romantis tersebut 
langsung disambung oleh adegan perseteruan Kale dan Dinda di rumah ketika Kale mempertanyakan alasan Dinda meminta putus. Adapun Dinda meminta putus dari Kale karena sudah berselingkuh. Momen lain penggunaan teknik crosscutting digunakan untuk menyambung adegan Kale dan Dinda berciuman di dalam studio diikuti adegan Kale dan Dinda duduk dengan tatapan kosong. Ketidaksinambungan gambar yang ditampilkan dalam penggunaan teknik crosscutting justru memiliki tujuan untuk memberikan kesinambungan cerita (Agung Sugihartono \& Ali, 2015, p. 77). Setelah adegan Kale meminta Dinda menjadi pacar, adegan berikutnya disambung oleh adegan dimana Kale berusaha menerima kesalahan Dinda dan mengajak Dinda memulai semuanya dari awal. Awal yang Kale maksud tidak lain adalah awal ketika mereka mulai berpacaran, tergambar pada shot sebelumnya.

Adegan lain yang menggunakan teknik crosscutting juga terdapat pada momen ketika Kale merasa tidak bisa membahagiakan Dinda, dalam suasana sedih ia duduk di depan piano kemudian adegan tersebut disambung oleh adegan flashback dimana tergambar romantisme antara Kale dan Dinda ketika sedang menciptakan lagu. Dalam adegan romantis tersebut fokus penonton diarahkan kepada Dinda melalui penggunaan shot close up. Diiringi lagu ciptaan mereka, Dinda mengatakan bahwa ia tidak hanya berselingkuh namun juga hendak menikah. Di momen tersebut lamunan penonton pada romantisme Kale dan Dinda seakan dirusak oleh perkataan Dinda sekaligus menghadirkan waktu kembali ke masa sekarang.

\section{Conclusion}

Dalam penggarapan sebuah film drama, alur dan kemasan sebuah cerita merupakan subyektifitas sutradara, penulis skenario, dan editor dalam merangkai adegan satu dengan yang lain sehingga bisa dinikamati dan memiliki kekhasan sebagai sebuah pertunjukkan audio visual. Namun, penggunaan alur baik maju, mundur, maupun kombinasi antara kedua bentuk alur tersebut hendaknya didasarkan pada struktur naratif yang baik dan terbukti mampu menarik perhatian penonton secara luas.

Film Story of Kale merupakan spin off dari film Nanti Kita Cerita Tentang Hari Ini. Sehingga bila menilik dari struktur cerita dan gaya kemasan Story of Kale, tidak heran bila kemudian gaya kemasannya sangat identik dengan cerita film Nanti Kita Cerita Tentang Hari Ini. Bila dilihat dari urutan waktu cerita, basic story film Story of Kale memiliki struktur dramatik naratif tiga babak dimana tahap awal, tengah dan akhir merupakan urutan sejak Kale melerai perselisihan Dinda dan Argo, dilanjutkan hubungan Kale dan Dinda dengan segala konflik yang semakin besar karena idealisme masing-masing individu hingga berakhir pada perseteruan di rumah yang ditutup oleh kerelaan Kale melepas kepergian Dinda. 
Struktur tiga babak cerita dengan alur maju tampaknya justru tidak disajikan dalam film berdurasi 77 menit tersebut, namun menggunakan alur mundur yang menampilkan dua segmen cerita. Yang pertama adalah segmen perseteruan Kale dan Dinda di rumah, yang kedua adalah kumpulan flashback sebagai insert dari perseteruan. Dalam mengemas insert flashback, teknik editing crosscutting digunakan untuk memberikan kesinambungan cerita dalam visual yang tidak berkesinambungan.

Cerita Story of Kale sejatinya memiliki dasar struktur naratif yang cukup kuat, terbukti dari kaidah tahapan-tahapan yang digunakan dalam plot cerita kronologisnya, namun pembuat film justru tidak menampilkan hal tersebut sebagai kemasan akhir. Alih-alih memberikan konsep suasana alur mundur melalui insert scene yang mempertegas cerita di setiap dialog perseteruan, alur cerita film tersebut malah terkesan memaksakan susunan adegan yang justru melemahkan dramatisasi konflik dan klimaks cerita film itu sendiri.

\section{References}

Agung Sugihartono, R., \& Ali, M. M. (2015). Teknik Editing Pada Film Rectoverso Dalam Mewujudkan Cerita. Capture, Jurnal Seni Media Rekam, 6(2), 69-84. http://jurnal.isiska.ac.id/index.php/capture/article/view/763

Akbar, B. (2017). Struktur Film. Avant Garde, 5(2).

Amalia, W. P., Setiawan, B., \& Maret, U. S. (2019). Pemanfaatan Nilai Peduli Sosial Cerita Rakyat Di Kabupaten Purbalingga Sebagai Pengembangan Pendidikan Karakter Dalam Pembelajaran Bahasa Indonesia. Basastra, 6(2), 221-230.

Ardiansyah, A. G., Buda, I. K., \& Prabhawita, G. B. (2021). Film Fiksi Tentang Fenomena Toxic Positivity “ Balada Nanda Mencari Nama .” Cala Citra, 01(01), 6-17.

Aristo, T. J. V. (2018). The Influences Of Flashback To The Plot “The Iron Lady" Movie. Vox Edukasi Jurnal Ilmiah Ilmu Pendidikan, 9(1), 1-10.

Asri, R. (2020). Membaca Film Sebagai Sebuah Teks : Analisis Isi Film "Nanti Kita Cerita Tentang Hari Ini (NKCTHI).” Jurnal Al Azhar Indonesia Seri Ilmu Sosial, 1(2), 74-86.

Bianus, A. B. (2017). Fakta Cerita Dan Struktur Plot Filem Aksi Malaysia: Analisis Filem Lari ( 2013 ). E Bangi Journal of Social Science and Humanities, Universiti Kebangsaan Malaysia, 12(2), 214-228.

Bordwell, D., Thompson, K., \& Smith, J. (2017). Film Art: An Introduction (11th ed.). McGraw - Hill Education.

Cahaya Tarsisty, R. C., Farady Marta, R., \& Fernando, J. (2021). Menelusuri Sosok Kartini Melalui Liniearitas Alur Naratif Propp Dalam Novel Biografi Karya Pram. Jurnal 
Komunikasi, 15(2), 137-152. https://doi.org/10.20885/komunikasi.vol15.iss2.art5

Cendekia, D. (2020). Meraba Bentuk Inciting Incident dalam Film-film Puzzle. Imaji, 11(1), $38-45$.

Erwani, I. (2017). Ekranisasi Alur Cerita Pada Novel (Jīnlíng Shísān Chāi)《金陵十三 钗》

Karya Yán Gē Líng Ke Film the Flower of War (Sebuah Kajian Alih Wahana). Jurnal Cakrawala Mandarin, 1(1), 40-74. https://doi.org/10.36279/apsmi.v1i1.33

Field, S. (2005). Screenplay: The Foundations of Screenwriting (revised). Delta.

Firziandini, I., Haryanto, D., Ilham, M., Studi, P., Budaya, F. I., Jember, U., \& Kalimantan, J. (2018). Analisis Struktur Naratif Pada Film Merry Riana Mimpi Sejuta Dolar Dalam Membangun Adegan Dramatik. Publikasi Budaya, 6(2), 140-146.

Kholisoh, N., Andika, D., \& Suhendra. (2021). Short Film Advertising Creative Strategy In Postmodern Era Within Software Video Editing. Bricolage: Jurnal Magister Ilmu Komunikasi, 7(1), 41-58.

Kristianto, B. R. D., \& Marta, R. F. (2019a). Monetisasi Dalam Strategi Komunikasi Lintas Budaya Bayu Skak Melalui Video Blog Youtube. Lugas, 3(1), 45-56.

Kristianto, B. R. D., \& Marta, R. F. (2019b). Simplifikasi Ritual Harai Dan Dimensi Kultural Hofstede Dalam Iklan Forte Versi Sumo. Bricolage : Jurnal Magister Ilmu Komunikasi, 5(1), 91-102.

Mulia, P. B. (2017). Cross-Cutting : Pembentukan Konflik Dalam Film "Haji Backpacker." Ekpresi Seni. Jurnal Ilmu Pengetahuan Dan Karya Seni, 19(2), 193-208.

Nurhablisyah, \& Susanti, K. (2020). Analisis Isi “ Tilik”, Sebuah Tinjauan Narasi Film David Bordwell. Jurnal Ilmu Komunikasi UHO, 5(4), 315-329.

Sari, A. A., Agung, A., Dian, A., \& Aritonang, B. D. (2020). Unsur Intrinsik Dalam Film Blue Spring Ride Karya Sutradara Takahiro Miki. Sphota: Jurnal Linguistik Dan Sastra, $12(2), 22-34$. 